The study deals with the formation of the idea of the national bistory among the Muslim Tatars of the Russian Empire in the periodicals in the early 20 century. The study's analysis is based on the materials of the journal "Shura" (1908-1917). Discussions about the bistory of the Turkic Tatars were built around the concepts of "our bistory" (taribymyz) and "national bistory" (tarib-e milli and milli tarib). The ideas about "our history" in the journal "Shura" were formed through the construction of the "glorious bistory" of the Turks and the creation of the image of a civilized (madani) nation. Discussions about national history allow us to reveal whom the authors of the publications attributed to the category "our ancestors" and what traits were attributed to them. The interpretation of the Turko-Tatar history was considered to be distinctive for this periodical (A. Assmann).

Keywords: bistory of the Russian Empire, bistory of Islam in Russia, the Tatar periodical press, journal "Shura", Rizaetdin Fabretdin.

Junior Research Fellow,

A.E. Krymsky Institute of Oriental Studies, National Academy of Sciences of Ukraine (Kiev)

Dilyara Brileva 


\section{ТАРИХ-Е МИЛЛИ: «СВОЯ ИСТОРИЯ» В ЖУРНАЛЕ «ШУРА»}

\section{Диляра Брилева}

diliarabrileva@gmail.com

DOI: http://dx.doi.org/10.24848/islmlg.10.1.03

Настоямее исследование посвящено формированию представления о начиональной истории татар-мусульман на страницах периодической печати Российской империи начала XX 8. Работа основанана ана-

Диляра Брилева

Mrадиий научньцй сотрудник Инстиmута востоковедения имени A.E. Крьммского, Национальная академия наук Украинь (2. Киев) лизе материалов журнала «Шура» (1908-1917). Аискуссии об истории тюрко-татар строились вокруг понятий «своя история» (тарихьмыьз) и «начиональная история» (тарих-е милли и милли тарих). Предстаһления о «своей истории» В журнале «Шура» формировались через построение «слабной истории» тюорок и создания образа чивилизованной (мәдәни) начии. Рассуждения о начиональной истории позволатот судить о том, кого авторь публикачий относили к категории «наши предки» и какие черть им приписььвали. Интерпретаиия истории тюрко-татар рассматривается в качестве присущей данному, отдельно взятому изданию (А. Ассман).

Ключевые слова: история Российской империи, история ислама ८ России, татарская периодическая печать, журнал «Шура», Ризаэтдин Фахретдин.

\section{ВОПРОСЫ ИСТОРИИ В ТАТАРСКОЙ ПЕРИОДИКЕ НАЧАЛА ХХ В.}

$\mathrm{B}$

конце XIX - начале XX веков начинает складываться татарская историческая наука. Этот процесс происходиц парамлельно с поисками идентичности в среде татарской мусульманской интемлигенции Российской империи и отчасти должен был явиться ответом на вопрос: «кто мы?» При этом историческая наука скмадывацась как из текстов татар-мусульман, написанных на территории Российской империи, так и созданных авторами, пребывавших в эмиграции. Например, Ф. Шакуров (2002, с. 30-50), рассматривая формирование представлений о «своей истории» у татар-мусульман рубежа XIX-XX вв., подробно анализирует работы Габдеррашида Ибрагимова (1857-1944), Ризаэтдина Фархретдина (1859-1936), Хасан-Гата Габаши (1863-1936), Гайнетдина Ахмарова (1864-1911), Гарифулмы Салихова (? - ок. 1915), Хади Атмаси (1876-1938), Ахмад-Заки Валиди (1890-1970), ГабдемБари Баттала (1880-1969), Мурада Рамзи (1855-1934), Курбангали Халиди (1846-1913). Важ- 
но, что национальная история, создаваемая в начале XX в., конструировацась не внешними по отношению к татарскому мусульманскому сообществу России авторами из числа православных миссионеров и «западных» востоковедов, а самими мусульманами (Усманова, 2004, c. 110). В то же время здесь речь идет не о религиозных трактовках татарской истории, а о формировании светской истории. Первым же этапом становцения светской истории стацо обращение к «истокам»: к ранней истории тюркских народов, к Аревней истории тюркотатар и их наиболее значимых государственных образований (там же, с. 113).

Наиболее известными авторами, писавшими исторические сочинения, являются Шигабутдин Марджани (1818-1889) и упоминавшийся выше Ризаэтдин Фахретдин. ОАин самых известных трудов Шигабутдина Марджани посвящен истории Волжской Булгарии, Золотой Орды и Казанского ханства - «Сведения о положении дел в Казани и Булгаре» («Мөстәфадел-әхбар фи әхвали Казан вә Болгар») ${ }^{1}$. Примечательно, что труд по «своей истории» Марджани написал на «своем языке» - на (старо)татарском, в отличие от большинства остацьных его сочинений (преимущественно теологического содержания), написанных на арабском (Миргалеев, Абызова, 2018, с. 184). Кроме того, «Сведения...» стаци первой книгой по истории татар, написанной на (старо)татарском языке (Schamiloglu, 1990, p. 42). Из-под пера Р. Фахретдина вышио не одно произведение, посвященное истории татар. ОАнако наиболее значимыми текстами явцяются «Асар» («САеды») ${ }^{2}$ и многочисленные статьи исторического содержания, опубликованные в журнаце «Шура» («Совет»), бессменным редактором которого он явцялся на протяжении всех десяти мет существования издания.

Формально официальная история татарской периодической прессы восходит к тем изменениям, которые произошии после подписания Манифеста 17 октября 1905 г., когАа появляется и начинает стремительно развиваться периодическая пресса татар-мусульман 3 . По подсчетам А. Усмановой, между двумя революциями 1905-1907 и 1917 гг. выходици 76 периодических изданий (Усманова, 2013, с. 149). Но далеко не все газеты и журналы выходили регулярно и диительное время. Часть изданий прекратила свое существование по политическим и финансовым причинам. Издания часто определяли свою направленность как митературную, а также как политическую, религиозную, научную, образовательную и даже сатирическую.

Специальных исторических журналов не существовало, тем не менее к вопросам истории татар, тюрко-татар, тюрок-мусульман на страницах периодической печати татар-мусульман Российской империи начала XX века обращались часто. Создание четкого образа нации являлось важнейшей задачей интелмектуальной элиты татар-мусульман, что расценивалось как необходимое условие Аля оформления нации и среди прочего требовало изучения «своей истории» (Усманова, 2004, с.117). В то же время,

1. Первое переложенное на кирициицу издание этой книги увидело свет еще в 1989 г., однако раздел по золотоордынской истории, а также разделы, посвященные другим татарским ханствам, кроме Казанского, в него не вошли (Миргалеев, Абызова, 2018, с. 184). Позднее раздел, посвященный золотоордынскому периоду, вышел в виде отАельной статьи с комментариями (Миргалеев, Абызова, 2018). Что касается научной митературы, Марджани как историку посвящены три статьи в Аевятом томе журнала «Islamology», вышеАшем по случаю 200-летия со дня рождения Ш. Марджани: (Bustanov, 2019; Ахунов, 2019; Хайрутдинов, 2019).

2. «Асар» явмяется многотомным историческим сочинением Р. Фахретдина. Среди его значимых исторических сочинений современники отмечали упомянутый «Асар» и статьи, выходившие в журнале «Шура» (Шәрәф, 1916, с. 311), что будет отмечено ниже.

3. В то же время стоит отметить, что первые издания на тюркских языках на Кавказе, в Крыму и в Туркестане стали появляться и раньше. Особую роль играла двуязычная газета «Терджиман»/ Переводчик» И. Гаспринского, изАававшаяся в г. Бахчисарае в 1883-1918 гг. В условиях отсутствия периодики важное значение имели цитературно-публицистические альманахи, главным из которых был «Миръат» («Зеркало»), издаваемый Габдеррашитом Ибрагимовым в Санкт-Петербурге и Казани в 1900-1909 гг. (Усманова, 2013, с. 148). 
«с точки зрения развития татарского наџионацьного проекта не существовало четких границ между публицистикой и историографией. Квинтэссенцией интелмектуальных Аебатов того времени, пересекавших граниџы пубциџистики и историографии, была перманентная дискуссия о самоназвании - тюрки ици татары - на страниџах журналов «Совет» («Шура») и «Сознание» («Анг»), а также на засеАаниях мусульманских съездов и «Национального собрания» («Мицият мэжлесе») в 1917-1918 годах» (там же, с. 114).

В журналах «Шура» («Совет») и «Аң» («Сознание») проходици дискуссии, посвященные понятию «нация» («мимләт») и таким сопряженным с ним категориям, как религия, история, территория, проблема этнонима. В отдельных случаях дискуссии инициировались и модерировацись реАакциями изданий, которые преАлагали читатеАям вступить в дискуссию, предоставив ответы на анкетные вопросы. В частности, один из вопросов анкеты, опубликованной в журнале «Аң» в 1913 г., касался отношения читателей к национальной истории (Усманова, 2018).

\section{ИСТОРИЯ ТАТАР В ЖУРНАЛЕ «ШУРА»}

B

настоящей статье исследуется формирование образа «предков» через интерпретацию «своей истории» в журнале «Шура». Здесь я буду рассматривать, какой авторы исторического Аискурса хотели видеть «свою историю», что стремицись вкАючить в послеАнее и почему.

Журнал «Шура» выходил в Оренбурге в 1908-1917 гг. под редакцией публициста, ученого и религиозного деятеля Р. Фахретдина. За эти десять мет было издано ровно 240 номеров. Журнал представлял собой площадку, где обсуждались важные вопросы современности, как правицо, социального и богословского значения. На страниџах издания могли быть высказаны разные позиции по одному и тому же вопросу. Кроме того, активная позиция главного редактора, которая предполагала взаимодействие редакции с подписчиками, позволяла последним обращаться в реАакцию с вопросами по тому или иному вопросу и получать на них ответы от наиболее свеАущих миџ. При этом реАакщия оставляла за собой право прокомментировать спорные высказывания своих авторов. Эти особенности функщионирования издания делаци журнац «Шура» местом, где возникала возможность ведения дискуссий и в нашем случае - конструирования своего видения истории тюрко-татар.

В первом же номере издания за 1908 г. среди планируемых девяти рубрик первые Аве были выделены под рассмотрение исторических вопросов. Первая из них называ-

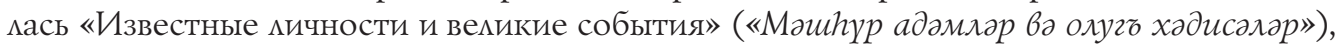

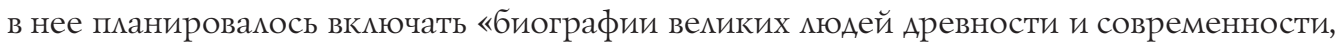
повествовать о падишахах и вкратце рассказывать о географии и истории этих стран». Вторая же рубрика носила название «Статьи» («Мәкаләләр») и должна была охватывать

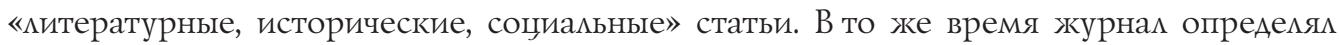
себя как «митературный, научный, политический» и не делац акцента на исторической тематике. Журнац являлся наиболее авторитетным изданием своего времени, что объяснялось, с оАной стороны, Аичностью самого главного реАактора, а с Аругой - подборкой авторов, публиковавшихся в нем. Вес издания в глазах читательской аудитории, взвешенность подхода главного редактора в вопросах пубцикации материалов, отстаивающих различные позиции по обсуждаемым проблемам, и дискуссионный характер публикуемых материалов - все это наряду с продолжительным сроком выхода издания делает этот журнац важным источником дия изучения. 
В статье исследуются материалы журнацьных публикаций, в которых присутствоваци Аискуссии о значении нащиональной (милли) истории как науки, выстраивались гранищы, охватывавшие национальную историю, ставились акценты на тех или иных исторических событиях и мичностях, а также Аавалась оценка этим событиям и мичностям. При этом основным понятием, вокруг которого строились дискуссии о истории татар, было понятие о «своей истории» (mарихьљьљ - буквально «наша история»). В этом же значении применялись понятия «национальная история» (милли тарих и тарих-е миллич). Поэтому, следуя могике авторов дискурса в журнале «Шура», мы используем эти два понятия как ключевые.

Поскольку в рамках Аанного исследования я руководствовалась конкретным концептом, который позволяет систематизировать анализируемый материац, статьи, выходившие в упомянутой рубрике «Известные кичности и великие события» не рассматриваются, т. к. в них приводятся искАючительно биографические Аанные, мало эмоџиональной и оџеночной информации, которая позволила бы судить о том, какой виделась национальная история авторам дискурса, формировавшегося в татарской печати начала ХХ в.

Редакция журнала «Шура», как и многие другие татарские периодические издания, практиковала жанр «вопрос-ответ», в рамках которого читатели могли обращаться с вопросами и получать ответы как от самого редактора журнаца, так и от постоянного авторского комлектива. Эти небольшие заметки также вошли в круг источников.

Несмотря на то, что формально авторство статей без подписи, которых за десять цет издания журнала было немало, остается спорным, ряд ученых предполагает, что анонимные статьи относицись ици могли относиться к авторству самого Ризаэтдина Фахретдина (Dudoignon, 2006, р. 102). Поэтому можно говорить, что журнац «Шура» во многом представця собой труА одного автора или же, по меньшей мере, был сильно подвержен вциянию своего главного редактора (там же, р. 101).

Этот подход к исследуемому материалу определяет и методологическую основу работы. Как утверждает Алейда Ассман, развивая идею Ниџше о «памяти воли», «институции и корпорации, а также культуры, нации, государства, церковь или фирма "не имеют" памяти, ибо она "конструируется" ими с помощью мемориальных знаков и символов. Благодаря этой памяти институции и корпорации одновременно «конструируют» собственную идентичность» (Ассман, 2007, с. 21). Поэтому то видение «своей истории», которая конструировалась в журнале «Шура», мы будем рассматривать как свойственное конкретно этому изданию и не будем распространять на всю периодическую печать татар-мусульман, которая существовала между двумя револющиями 1905 и 1917 гг.

\section{ПРОБЛЕМА РАЗГРАНИЧЕНИЯ СВОИХ И ДРУГИХ В ТАТАРСКОЙ ПРЕССЕ НАЧАЛА ХХ В.}

B проџессе изучения «своей истории» (тарихьмьљз) встает проблема разграничения сbоих и других. Какие народы, какие этнические группы относились к категории «своих» на момент формирования дискурса периодической печати? Население каких территорий рассматривалось авторами периодической печати как часть «своего» в исторической перспективе?

Ответы на эти вопросы позволяют определить, что понималось авторами публикаций журнала «Шура» поА «своей историей». При этом стоит отметить, что вопрос раз-

4. Эти два термина явцяются идентичными по своей сути и разцичаются лишь грамматическими особенностями. Так, в первом случае использован тюркский вариант сочетания определения и определяемого, во втором - так называемый персидский изафет, характерный дмя (старо)татарского языка 
граничения «своей наџии» / «своего народа», или, если говорить языком авторов дискурса татар-мусульман Российской империи начала XX в., «своего миллета», поднимался не только в статьях исторического характера. Mиллет (в татарской фонетической традиции - милләт) происходит от арабского «millaһ», что переводится как «нация», «религия». Это важная деталь в понимании значения данного концепта, который стоял во главе угла масштабных дискуссий в периодической прессе татар-мусульман. Значение этого слова на арабском во многом соответствует тому наполнению понятия, которое существовало в понимании татарского населения начала XX в. и которое подразумевало, прежде всего, религиозную общность 5 . Так, в печати упоминается, что среднее поколение предпочитает называться мусульманами и не использует слова «татарин» или «тюрок» Аля самоопреАеления (Габиди, 1911, с. 116-117). Р. Ажераси также указывает на первичность религиозной составцяющей комлективной идентичности татар-мусульман (Ажераси, 2013, с. 344). В дискурсе татар-мусульман начала XX в. понятие миллет часто появлялось в формулировке «прогресс нации» или таракки-е миллет. Прогресс нации в дискурсе становился важнейшей целью и ценностью, во имя которой затевались публичные обсуждения различных социальных/богословских вопросов (Брилева, 2019b, с. 423).

Часто о разграничении сбоего и другого в публикациях журнала «Шура», как, впрочем, и Аругих изданий, можно судить, исходя из публичных обсужАений социальных и богословских проблем мусульманского сообщества Российской империи, в частности, и мусульманской уммы, в целом. Богословские вопросы в периодической печати татармусульман России начала XX в. часто рассматривацись в контексте соџиацьных преобразований мусульманского сообщества. Внесение ясности в существовавшие вопросы богословского характера в среде мусульманских интелмектуалов в понимании авторов Аискурса являлось необходимым условием дия развития миллетаб.

ОАнако в прессе татар-мусульман разграничение $c$ боего и другого не всегда осуществцялось единообразно. Так, в обсуждении одних проблем другими оказывались народы/ нации - миллетьи, которые обладали другой религиозной составцяющей комлективной идентичности. «Америка» и «Европа» как нация/миллет выступали другими в вопросах реформирования системы образования. В то же время другими могли оказаться и мусульмане Туркестана или Закавказья, когда речь заходица о бытовых и ежедневных практиках религиозного и нерелигиозного содержания. Таким образом, в печатном дискурсе татар-мусульман России существовали «другие мусульмане», которые, с одной стороны, являлись такими же мусульманами, как и «мы», и принадлежаци общемировому сообществу мусульман, а с Аругой стороны - в быту и в жизни представ яяии собой других.

Как уже упоминалось выше, дискуссии о «своей истории» в журнале «Шура» выстраивались вокруг концепта «наша история» («тарихьммьз»), который использовался в том же значении, что и «национальная история» (mарих-е милли/милли тарих). При этом под «национальной историей» понималась, прежде всего, общетюркская история или «история тюрко-татар». Определение содержания «мицли тарих» должно также способствовать пониманию понятия «миллет» ${ }^{7}-$ ключевого Аля периодической прессы татар-мусульман начала XX в., вокруг которого проводицись дискуссии по социаць-

5. В то же время важно иметь в виду, что наполнение понятия «милмәт» в современном татарском языке и татарском обществе несколько отличается от тех коннотаций, которые вкцадывались в этот термин в начале ХХ в. В частности, современное значение уже не распространяется на всех тюрок-мусульман, сужаясь до советского «татарского этноса». Часто это понятие используется в рамках выражения «татар милмәте» («татарский народ»).

6. Более подробно о связи богословских вопросов и прогресса в обшестве см.: (Брилева, 2019а).

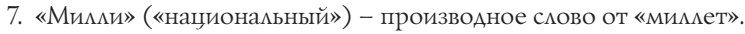


ным и богословским реформам. Какими бы разными авторам публикаций ни виделись возможные варианты решения проблем, сушествовавших в современном им обществе, главная ценность Аля всех групп заключалась в кучшей судьбе Аля миллета.

\section{ТАРИХ-Е МИЛЛИ: ОТ МУСУЛЬМАН К ТАТАРАМ}

$\mathrm{H}$ ациональная история в публичном дискурсе журнала «Шура» рассматривается авторами статей, опубликованных в издании, как важнейшая категория Аля формирования комлективной идентичности татар-мусульман Российской империи начала XX в. Распространение знания о наџиональной истории Аолжно было способствовать укреплению самовосприятия как тюрко-татар в противовес существовавшему самоопределению «мусульманин».

В рассуждениях авторов дискурса о национацьной истории предками выступают тюрки в целом: «...мы обладаем очень ограниченной информацией о жизни наших преАков (бабаларьциьз) - тюрок в целом...» (Гали, 1912, с. 716)

ици

Иу нас есть своя история. Аревние тюрки, которье одно время имели славу/честь (шан) и убажение (шәрәф), - наши убажаемьєе предки (Тарихымызга гаид, 1909, с. 391).

В журнале «Шура» говорят и о значении национальной истории, о необходимости знать ее: «Человек, который не знает своей национальной истории (милли тарих) и не придает ей значения, не является членом этой нации (милләт)» (Тарихымызга гаиА, 1909, с. 391).

Говоря о необходимости изучать и знать национальную историю, авторы используют религиозную аргументаџию. Иными словами, знание «своей истории» выступает важным условием Аля сохранения величия «ислама»:

Чтобь сберечь славу/честь (иан) и убажение (иәрәф) ислама и следовать пути благородньх сахабов, и нам следует читать историю <... И нам, прежде всего, следует знать историю сьоего народа - тюрок. Аля этого, прежде всего, нужно постепенно начинать преподавать... нашу начиональную историю (милли тарихыммыз) (Габаумлин, 1912, с. 531).

Еще одной целью, Аля достижения которой следовало изучать тарих-е милли, являлся рост национацьного духа. Способствовать этому должно было открытие национальных музеев:

В одном из прошльх номеров «Вакбт»а я упоминал о том, что для возрождения нашей начиональной истории (милли тарихымьљ) и для роста начионального духа (милли хис) у нашего народа одним из самьхх необходимьх условий является открььтие начионального музея (милли музеханд) (Фәхретдинов, 1909, с. 145).

Наибольшее значение в «своей истории» было необходимо уделять ранней истории тюрок: «Самым важным разделом в нашей собственной истории должны быть повествования о жизни Аревних тюрок» (Гали, 1912, с. 716).

Авторы обращали внимание читателей на отсутствие достаточного количества книг по «своей истории» и в особенности авторов, которые были бы готовы написать эти книги:

8. «Вакът» - газета, выходившая в г. Оренбурге в 1906-1918 гг. под редакцией Фатиха Карими (1870-1937) на средства золотопромышиенников Мухаммадшакира и Мухаммадзакира Рамиевых, которые являлись также издателями и журнала «Шура». 
«Как это случается со всеми народами, русские книги по истории создавались не с опорой на конкретнье доказательстьа, а делая «из двух кривьхх одного прямого». Но б то же время нельзя отрицать и то, ито русские историки извлекали информачию из архивов, надгробий, старьх монет, старьхх камней и оружия - в челом, путем проведения археологических раскопок. «Кривьхх сведений и у нас много; но недостает людей, способньх сделать «из двух кривьх одного прямого» (Тарихымызга гаид, 1909, с. 391).

В критической статье Галимджана Шарафа на сочинение Заки Вациди ${ }^{10}$ «Тюрко-татарская история» («Терек-татар тарихы»), изданное в 1912 г. в Казани, приводится разбор существовавших на тот момент книг по истории. Из этой статьи следует, что интерес к национальной истории у авторов стал появляться только в самом начале XX в.:

Аесять лет назад для ознакомления снашей историей (тарихьмыь) нанашем язьке (телемез) било лишь два источника посерьезнее. Один из них - перевод книги «Родословная тюрок» Абу ал-Ази Бахадирхана" на казанский тюоки. (Перевод вьполнен Габделгаллямом Фаезхан-угльь и бил издан в 1891 г. б Казани.) Второй же - «Мустафад ал-ахбар» Шихаб-хазрата Марджани (Шәрәф, 1916, с. 311).

При этом автор утвержАает, что выходившие в тот же период Аругие исторические труды не представмяци особой ценности:

«Несмотря на то, что бьли и другие сочинения на казанском тюрки..., они с исторической точки зрения бьли незначительньми и по большей части бъли полнь суеверий и преданий. И только пербье два были распространеньь среди народа» (Шәрәф, 1916, с. 311).

Автор статьи дает краткую характеристику книгам, выходившим в предыдущие десять кет.

Если Хасан-Гата хазрат Габаши 13 с соох произведениях «Подробная история тюркского народа» / «Муфассал тарих-е каум-е турки» и «Краткой истории тюркского народа» / "Мухтасар тарих-е каум-е турки», которое вьшло позднее, и 8 «торкских племенах» / «Турк ьругларь» стремится изучить тнокские племена, их отношение друг к рругу, их жизнь в старье времена, mо Ризаэтоин хазрат [Фахретдин - А.С.] через свои статьи $\beta$ «Шуре» и драгоченный "Асар» познакомил [нас - А.С.] с отдельньми личностями, заниматоиими Важное место б нашей дабней и недавней начиональной истории (милли тарихьмыз), и их деяниями. Трудь Гайнетдина Ахмерова ${ }^{14}$ открьли нам многие сторонь бремен Болгар [а - А.Б.] и Казан[ского ханства - А.Б.]. Хади эфенди Атласи ${ }^{15}$ написал «Историю Сибири» (Шәрәф, 1916, с. 311).

9. Галимджан Шараф (1886-1950) - ученый, писатель, общественно-политический деятель.

10. Заки Валиди (Ахмат-Заки Валиди, 1890-1970) - татаро-башкирский ученый, историк, востоковеА, общественнополитический деятель.

11. Здесь написание имени приведено в соответствии с оригиналом. В тексте ошибочно использована буква «айн» вместо «гайн». В Аанном случае речь идет о правителе Хивинского ханства и историке Абу ал-Гази Бахадирхане (1603-1664).

12. Габделгалмям Фаезханов (1850-1910) известен своим сочинением «Авигатель мыслей» («Мухаррик аль-афкар»), посвященным вопросам реформирования системы образования татар-мусульман; переводчик, педагог.

13. Хасан-Гата Габаши (1863-1936) - религиозный судья (казый) Оренбургского магометанского духовного собрания, историк.

14. Гайнетдин Ахмеров (1864-1911) - педагог и ученый.

15. Хади Атласи (1876-1938) - педагог, ученый, общественно-политический деятель. 
ОАним из главных моментов, которые подвергались критике в исторических текстах, явцялось сокращение излагаемой истории, верхняя граниџа которой приходицась на Волжскую Булгарию, а нижняя - на взятие Казани в 1552 г.:

Все сочинение оставляет впечатление, будто до появления Волжской Булгарии у татар - наших предкоб (бабаларымьљ) - не бьло своей истории, да и после падения Казанского ханства у них не бьло истории (Шәрәф, 1916, с. 312).

И в отношении труда Заки Вациди «Тюрко-татарская история» Г. Шараф также отмечает, что один из главных недостатков труда заключался в том, что «тюркским госуАарствам, которые были до Чингиз-хана, не было уделено Аолжного внимания» (Шәрәф, 1916, с. 313).

Что касается географических граниџ тех территорий, которые входили в категорию «нашего родного края» (мәмләкәтемез), Р. Фахретдин утверждает ${ }^{16}$, что

Стамбул и южная сторона Черного моря не являются нашим родньм краем (мәмләкәтемез) (Ибне Батутаның..., 1917, № 12, обложка).

О национальной истории говорицось довоцьно часто в контексте реформ в области реформирования системы образования, в обшем, и учебных программ, в частности. Национальная история называется одним из предметов, которые следовало вводить в школьные программы, что, в свою очередь, было необходимо Аля оформления своего представления о себе. Автор одной из статей обращает внимание читателей на то, что в татарских деревнях среди мюдей бытовало представление о себе как о мусульманах без отсылки к своему татарскому происхождению. Такое положение дец, по мнению автора, следовало исправлять путем внедрения национацьной истории в школы:

<...> у каждой начии (милләт) есть своя история. В иколах детям преподают историю, ктому же относятся кэтому с большим вниманием. Какими людьми бьли их предки и в какое время они жили - обо всем дают представление. Рассказььая о доблестньх поступках своих дедов, призььанот следовать их примеру, упоминая об их ошибках, призььанот не повторять их. Словом, наглядно учат их оберегать свою начиональнуто принадлежность (миллият) и способам сохранения своего существования (мәужудият). А теперь давайте обратимся к нашим школам: преподается ли история так, как это было упомянуто вьие? Знаюот ли наши дети о наших предках? Посвящень ли они в то, где и как они жили, и чьи ми потомками они являюотся? (Я името в виду школь низшего уровня. Потому что это самое важное. Мое мнение касается деревенских икол.) <...> Этого нет в наших школах. Ааже если есть, то на уровне мечтаний и грез. Oтсутствие этого имеет две причинь, но самое глабное $а$ том, что нет подходящих книг. Возможно, бьло бь лучше, если би вместо того, итобь ежемесячно писать об истории ислама (тарих-е ислам), в подходящем виде писалось бь о начиональной истории (тарих-е милли), пусть даже В единственном экземпляре. Правда, о своей истории (1з тарихьмыьз) есть некоторое количестьо книг, например, по истории тюркского народа (кавем-е төрки), истории Болгара, истории Казани... Найти себя в этих

16. Публикация вышиа в разделе «Вопрос-ответ» и формально не имеет подписи. 
книгах - сложное дело. <...> Короче, эти книги не В состоянии обгяснить нам, кем мь являемся. <...> У нас в деревнях дети вьнуждень заканчивать только начальную школу, и у них не бььвет ни малейшего представления о нашей истории (тарихьмызз). Если спросить у мужиин средних лет, они говорят: «Я - мусульманин!», не любят говорить «Я - татарин», так же, как не любят гоһорить «Я - тюрок ${ }^{17}$ (Габиди, 1911, с. 116-117).

Галимджан Шараф также указывает на то, что отсутствие книг по тарих-е милли приводицо к тому, что дети в школах не могли изучать национальную историю:

Но до 1912 года на натем язьке (телемез) не било сочинения, которое бы охватьљало историю тюркских народов с древних времен до наших дней, сьязььвало бь [собьтия - А.Б.] В одну чепочку принятьми в науке методами, рассматривало би взаимосвязь разньх эпох. Опсутствие подобньх трудов и в русской прессе еще более усложняло ситуачию. Это положение дел являлось очень большим препятствием для введения и закрепления начиональной истории (милли тарих) в мектебах ${ }^{18}$ и медресе ${ }^{19}$ (Шәрәф, 1916, с. 311).

По замечанию $\Lambda$. Усмановой, то, что создаваемые в начале XX в. национальные истории нередко принимали форму учебников дия шакирдов медресе, было неслучайно, поскольку в начале XX в. «шакирды представляли собой наиболее значительную по охвату читате ьскую аудиторию, а издание учебников обеспечивацо такому сочинению тиражи, немыслимые Аля иного рода изданий. Не в последнюю очередь создание национальных историй в виде учебных пособий было обусловлено потребностями реформируемых конфессиональных учебных заведений. ОАним из направлений реформирования АжаАидистами традиционной системы мусульманского образования было изменение учебных программ мектебов и медресе в сторону усицения светского компонента, увецичения количества светских предметов. В русле этих преобразований в учебные программы большинства Ажадидистких медресе в качестве отдельного предмета включалась история тюрко-татарских народов. А потому возникала острая потребность в учебных пособиях по национацьной истории, написанных на местном материале и на понятном Аля большинства населения языке» (Усманова, 2004, с. 111-112).

Таким образом, журнал «Шура» формирует миллет-центричный Аискурс, в котором тарих-е милли становится важным фактором дия развития национальной комлективной идентичности. Тарих-е милли, по мнению авторов статей журнала «Шура», было необходимо вносить в школьные программы, что требовало наличия книг и учебных пособий дмя обучающихся.

\section{ТАРИХ-Е МИЛЛИ: «СЛАВНАЯ ИСТОРИЯ» ПРЕДКОВ}

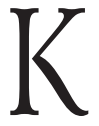

онструирование «своей истории» на страниџах журнала «Шура» основывалось на попытках осмысления военного прошиого своего народа, а также на создании образа цивилизованного (мәдәни) и просвещенного (мәгърифәтле) миллета.

Военное прошлое татарскими историками оџенивалось по-разному. Так, если Аля оАних участие предков (бабаларьмьљ) в военных сражениях и ведение войн было преА-

17. В Аанном случае понятие «тюрок» вкцючает в себя также и значение слова «турок», что характерно и Аля современного турецкого языка.

18. Мектеп (мәктәn) - начальная школа в системе образования татар-мусульман Российской империи.

19. Медресе (мәдрәсә) - средняя и высшая школа в системе образования татар-мусульман Российской империи. 
метом гордости Аля потомков, тем, что формировацо «славную историю» тюрко-татар, то по мнению Аругих, об этом не стоицо говорить пубцично, поскольку это не могло способствовать построению «скавной истории». В этой связи особый интерес преАставцяет уже упомянутая критическая статья Галимджана Шарафа, в которой он отмечает, что замалчивание биографии отдельных исторических иичностей, в частности, Тамерлана, характерно Аля ряда татарских историков, и выражает свое несогласие с такой позицией:

Как Шихаб хазрат в «Мустафад ал-ахбар» намеренно не останавливался на Тамерлане, так и Ризаэтдин хазрат, описььая биографии вьдағошихся личностей нашей начиональной истории (милли тарих) в своей «Шуре», пропустил Хромого Тимура. Заки Валиди тоже, вероятно, следуя за ними, в первой части опустил историю Тамерлана <...> Во Всех наших книгах по истории Хромой Тимур, государство, которое он построил, и история его детей отсутстьовали, и это бьло серьезньм недостатком. То, что наши историки ... не приветстьовали такого великого героя должным образом, казалось неубажением, так же, как и то, ито детей не знакомили с этим героем, о то время как знакомили с остальньми, - казалось преступлением (Шәрәф, 1916, с. 312).

Г. Шараф оценивает времена военного могущества тюрок как страницу из «славной истории» тюрко-татар:

Самьге могущестьеннье времена тюрок, когда всю остальную Азию держали 6 страхе, а больиую ее часть - b подчнении, Европе же не давали поднать головьь, ... автор уместил в половину-четверть страниць (там же, с. 313).

Поскольку «своя история» включала историю тюрко-татар, среди предков, которые творици «славную историю», оказывацись и Османы:

Во времена Османских правителей Селима I и Сулеймана I Великолепного, могущество тюрок не могло не привлечь внимания всей Европь. Превосходство тюрок во всем, во всех вопросах и во всех ситуачиях, указььало на то, что однаждь они обрушатся на Европу общей Волной. В те времена многие великие европейиь, вместо того, чтобь бояться этого нападения со сторонь тюрок, желали этого. Они верили, что приход тюрок избавит Eвропу от общественного устройства Средних веков и от угнетения властью nan (Мәржани, 1912, с. 82).

В то же время в дискурсе встречаются также и меланхолические нотки, которые в целом были характерны для дискурса татар-мусульман Российской империи начала ХХ в. Сравнивая былое величие Золотого века мусульман с современным положением мусульманской Уммы в целом и рассматривая последних как продолжение первых, авторы единогласно отмечали упадок, стагнацию. Эта оценка переносилась и на тюрок-мусульман:

Как говорят великие историки, история - это всего лишь повторение собьттии, могущества (иәукәт) и величия (газамат) в разньх местах и 8 разное время. Сейчас нет могушества Востока (шәрьк). Исчезло, погасло (Мәрқани, 1912, с. 84).

В рамках общественных дискуссий о «своей истории», Аискурсе прессы вырисовывается отдельная Аихотомия: Аикий (Вәхши) - цивицизованный (мәдәни). Эти Аве противопоцожные оценки используются дця построения апологетического дискурса. Авторы статей 
стремятся построить образ цивилизованного (мәдәни) и просвещенного (мәгбрифәтле) народа, вернув тюркам доброе имя и избавившись от обвинений в дикости «Вәхии»:

Несмотря на то, что тюрки являются самьюми древними и самьмии известньми народами мира, по причине кровопролитий, нарушения мира, они обрели славу полудиких людей <... Миру стало избестно, что и тюрки обладают трудами первостепенной важности в мире культурь (Үземезчел, 1912, обложка).

Галимджан Шараф также признает необходимость реабилитировать историю тюрко-татар и очистить ее от кмеветы:

А в последние десять лет количество сочинений, касатошихся нашей начиональной истории, значительно увеличилось и продолжает увеличиваться. При этом не только множится количество трудов, но и с точки зрения содержания происходит очень бьстрое развитие (тараккьй иту); число людей, работатоиих 8 этом направлении, также увеличивается. И все это дает надежду на то, что наша славная (ианль), но не ограненная, не изученная история, наша история, покрььтая пьлью и грязью, вскорости оживет и встанет на ноги и мь убидим, как она очистится от грязи (пьчрак), брошенной чужаками (читләр) (Шәрәф, 1916, с. 311).

В статьях прочитывается стремление объяснить военную активность преАков их мирными намерениями:

Однако эти войнь Велись не для того, чтобь награбить добьчу или сеять бокруг разруху, а скорее для того, чтобь противостоять нападениям со стороньи, отстоять свою честь (намус) или для открьтия рьнков сбьта. Несмотря на то, что русские историки и не говорят прямо об этой истине, 8 то же время и не умалчивают этого (Тарихымызга гаид, 1913, с. 10).

Образ цивилизованного и культурного народа в представлении авторов журнала «Шура» вкцючал в себя независимость, оседлость, земледелие, торговлю и разные виды ремесла:

Согласно сведениям арабских историков, булгарские тюрки бьли сильньми и иивилизованньми (мәдәни) и жили единьмм сообществом в городах, возделььвали землю и вели торговлю (Тарихымыз, 1912а, с. 558).

В ремесленном деле особую избестность получили кожанье изделия, булгарская кожа скупалась ина Востоке, ина Западе. Найденнье изделия подтверждалот мастерство булгар и в деле обработки металла (там же, с. 559). У булгар било великое государство и независимьий правитель <...> Цивилизованньий (мәдәниятле) и просвещенньй (мәгорифатле) народ, имевший свои ремесла <...> Государство у булгар бьло прочньми, а В науке и культуре [они - А.Б.] превосходили все остальнье народь (там же, с. 590).

«Славная история» тюрок имела крепкие связи с исламским миром. В частности, оАного из подписчиков интересовац вопрос о достоверности сведений, изложенных в $е-$ генде о приезде с миссионерской целью трех сахабо ${ }^{20}$ в Булгар. Согласно мегенде, спустя некоторое время двое из них уехали обратно в Медину, а один сыграл свадьбу с ханской Аочкой Туйбике и остался в Булгаре. Приведенная мегенда, и в особенности отношение

20. Сахаба - сподвижники пророка Мухаммада. 
к ней в прессе, представляется чрезвычайно важной в связи с тем, что позволяла конструировать историю исламизации региона, восходящую к сахабам. Журнал «Шура» в своем ответе указывает, что приезд сахабољ из Медины не был возможен по ряду причин, и прежАе всего, потому что в известных книгах по истории указаний на это событие нет (Болгарга сәхабәләр..., 1912, с. 507).

Отдельно подчеркивались связи с Россией. Так, «славная история» вкцючала в себя и давние Аружеские отношения с русскими землями:

Рассказььватся, что [булгарские тюрки - А.Б.] ездили в Суздаль и строили для князей церкви, а в голоднье годь обеспечивали всех суздальиев хлебом (Тарихымызга гаид, 1913, с. 10).

Кроме того, вкцюченность в имперский контекст упоминалась с целью конструирования «сиавного прошиого»:

Аоказательством Величия Булгарского государства может служить и то, что титул российских императоров до сегодняиних дней содержит [тиmул - А.Б.] «князь Болгарский» (Тарихымыз, 1912b, с. 590).

Национальная история в представлении авторов публикаций журнала «Шура» виАится как «славная история» тюрко-татар. В статьях звучит призыв реабилитировать Аоброе имя тюрко-татар и «очиститься» от клеветы, возведенной на миллет. «Славная история», таким образом, объединяла воинскую доблесть тюрок с образом цивицизованного (мәдәни), осеАлого народа с развитой наукой и ремеслами.

\section{ЗАКЛЮЧЕНИЕ}

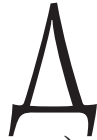

искурс об истории тюрко-татар, с одной стороны, явцялся частью пубцичного комлективного рассуждения о судьбе нации/народа (миллета). Концепты «своя история» (тарихымыз) и «национальная история» (mарих-е милли и милли таpux) выступали первичными по отношению к «прогрессу нации» (mаракки-е миллет), во имя которого и затевацись все дискуссии в татарской печати разной направленности.

С Аругой стороны, осмысление истории в периодической прессе татар-мусульман Российской империи начала XX в. являлось частью общего реформаторского дискурса. О необходимости развивать национацьную историю как науку говорится в связи с реформами в области школьного образования. Национальная история, внедренная в шкомы нового образца, должна была способствовать вытеснению из среды населения самоопределения «мусульманин» и укреплению самоназвания «татарин». Верхняя граница истории тюрко-татар не ограничивалась Булгарским государством и охватывала более ранние периоды. Кроме того, национальная история в понимании авторов статей, публиковавшихся в журнале «Шура», вкцючала в себя и историю тюрок в широком смысме. В частности, «славная история» Османской империи рассматривалась как важная составцяющая часть в построении образа «наших предков».

Аискуссии о тарих-е милли скиадывацись в «славную историю» преАков. Версия истории тюрко-татар, представленная в журнале «Шура», опиралась на возвращение военной активности предков в категорию «славного» и построение образа цивицизованной (мәдәни) наџии. При этом в центре Аискурса об истории оказывается Аихотомия дикий (Әәхии) - цивицизованный (мәдәни), а конструируемая «своя история» обретает форму через реабимитацию доброго имени тюрко-татар. 


\section{ИСТОЧНИКИ И ЛИТЕРАТУРА}

Ассман А. (2007). Алинная тень прошиого. Мемориальная культура и историческая помитика. М.: Н $\Lambda \mathrm{O}$.

Ахунов А. (2019). Проблема исламизации Поволжья в трудах Ш. МарАжани. Islamology, 9 (1-2), 149-160.

Болгарга сәхабәләр кимү-киммәу турында сорау һәм жавап. (1912). Шура, 16. 507.

Брилева А. (2019а). Аискуссии о тафсирах Корана в периодической прессе татар-мусульман Российской империи начала ХХ в. (на материалах журнала «Шура»). Вестник Московского университета. Серия 13. Востоковедение, 3, 19-31.

Брилева А. (2019b). Концепция «нового мусульманина» между Авумя революциями (по материалам журнала «Шура», 1908-1917). Государстьо, религия, иерковь в России иза рубежом, 1/2 (37), 417-433. DOI: 10.22394/2073-7203-2019-37-1/2-417-433.

Габлумлин Х. (1912). Татар тарихы хакында. Шура, 17, 531.

Габили М. (1911). Тарих-е мимли. Шура, 4, 116-117.

Гали Х. (1912). Иске төркләрдә тормыш. Шура, 23, 716-718.

Ажераси Р. (2013). Окно на Восток: Империя, ориентализм, нация и религия в России. М.: Новое митературное обозрение.

Ибне Батутаның Кыпчакка сәяхәте хакында сорау һәм жавап. (1917). Шура, 12, 2 m.б.

Мәржани, М. (1912). Тарихтан бер мәүхә. Шура, 3, 82-84.

Миргалеев И., Абызова Р. (2018). Шихабетдин Марджани о Золотой Орде. Золотоордъчнское обозрение, 6(1), 181-198. doi: 10.22378/2313-6197.2018-6-1.181-198.

Тарихымыз (1912а). Шура, 18. 558-559.

Тарихымыз (1912b). Wyра, 19. 590-591.

Тарихымызга гаид (1909). Шура, 13, 391-393.

Тарихымызга гаид (1913). Шура, 1, 10-12.

Усманова А. (2004). Создавая национальную историю татар: историографические и интелмектуальные дебаты на рубеже веков. Новая имперская история постсоветского пространства: сборник статей (библиотека журнала «Аb Imperio»). Под реА. И.В. Герасимова, С.В. Гиебова, А.П. Каплуновского, М.Б. Могицьнер, А.М. Семенова. Казань: Центр исследований нащионализма и империи, 109-126.

Усманова А. (2018). Поиски идентичности в эпоху национацизма: дискуссии о «мусульманской» и «тюрко-татарской» наџии среди волго-урацьских татар России в начале XX столетия. Электронньй научно-образовательньй журнал «История». Т. 9. Вьюпуск 8 (72) [Электронньй ресурс]. Аоступ для зарегистрированньцх пользователей. URL: http:/ / history. jes.su/s207987840002441-4-1 (Аата обрашения: 15.09.2020). DOI: 10.18254/S0002441-4-1.

Усманова А. (2013). «Национальная татарская периодическая печать отличается всюду одинаковостью направления...». Татарская периодическая печать 1905-1916 гг.: количественная и качественная характеристика. Симбирский научный вестник, 3 (13), 147-153.

Үземезчем (1912). Төркләр хакында. Шура, 23. 2-3 т.б.

Фәхретдин Р. (1908). Мәсләк вә максат. Шура, 1, 1.

Фәхретаинов Г. (1909). Мимли музаханәбез. Шура, 5, 145-147.

Хайрутдинов А. (2019). Мечети региона Заказанье в трактате Ш. Марджани «МустафаА ац-Ахбар фи Ахвали Казан ва Бумгар». Islamology, 9 (1-2), 161-177.

Шакуров Ф. (2002). Развитие исторических знаний у татар до февраля 1917 года. Казань: Издательство Казанского университета.

Шәрәф Г. (1916). «Төрк-татар тарихы» (Зәки әфәнде Вәлиди әсәре). Шура, 13, 311-314.

Bustanov, A. (2019). Shihabaddin Mardjani and the Muslim Archive in Russia. Islamology, 9 (1-2), 139-148.

Dudoignon S. (2006). Echoes to al-Manar among the Muslims of the Russian Empire. A preliminary research note on Riza al-Din b. Fakhr al-Din and Sura (1908-1918). Intellectuals 
in the Modern Islamic world. Transmission, transformation, communication. London-New York: Routledge, 85-116.

Schamiloglu U. (1990). The formation of a Tatar historical consciousness: Şihabäddin Märcani and the image of the Golden Horde. Central Asian Survey, 9 (2), 39-49.

\section{REFERENCES}

Ahunov A. (2019). The problem of Volga region Islamization in the works of Shihabaddin Mardjani. Islamology, 9 (1-2), 149-160 (in Russian).

Assmann A. (2007). The long shadow of the past: cultures of memory and the politics of history. Moscow: NLO (in Russian).

Question and answer of whether the Sahabah came to Bolgar. (1912). Shura, 16. 507 (in Tatar).

Brileva D. (2019a). Discussions About Tafsirs of the Qur'an in the Periodical Press of the Muslim Tatars of the Russian Empire in the Early Twentieth Century (on the Materials of the Journal «Shura»). Vestnik Moskovskogo universiteta. Serija 13. Vostokovedenie, 3, 19-31 (in Russian).

Bustanov A. (2019). Shihabaddin Mardjani and the Muslim Archive in Russia. Islamology, 9 (1-2), 139-148.

Dudoignon S. (2006). Echoes to al-Manar among the Muslims of the Russian Empire. A preliminary research note on Riza al-Din b. Fakhr al-Din and Sura (1908-1918). Intellectuals in the Modern Islamic world. Transmission, transformation, communication. London - New York: Routledge, 85-116.

Fehretdin R. (1908). Course and purpose. Shura, 1, 1 (in Tatar).

Fehretdinov G. (1909). National Museum. Shura, 5, 145-147 (in Tatar).

Gabdullin H. (1912). On the Tatar history. Shura, 17, 531 (in Tatar).

Gabidi M. (1911). National history. Shura, 4, 116-117 (in Tatar).

Gali H. (1912). Ancient Turks' life. Shura, 23, 716-718 (in Tatar).

Gerasi R. (2013) Window on the East: National and Imperial identities in late Tsarist Russia. Moscow: NLO (in Russian).

Hajrutdinov A. (2019). Mosques of the Zakazanye region in the Mustafad al-Akhbar fi Ahwali Kazan wa Bulgar treatise by Sh. Mardjani. Islamology, 9 (1-2), 161-177 (in Russian).

Question and answer on Ibn Batuta's trip to Kypchak. (1917). Shura, 12, 2 t.b. (in Tatar).

Merjani M. (1912). A page of history. Shura, 3, 82-84 (in Tatar).

Mirgaleev I., Abyzova R. (2018). Shihabutdin Marjani on the Golden Horde. Zolotoordynskoe obozrenie = Golden Horde Review. (6) 1, 181-198. DOI: 10.22378/2313-6197.2018-6-1.181-198 (in Russian).

Schamiloglu U. (1990). The formation of a Tatar historical consciousness: Şihabäddin Märcani and the image of the Golden Horde. Central Asian Survey, 9 (2), 39-49.

Shakurov F. (2002). The development of historical knowledge among the Tatars until February 1917. Kazan': Izdatel'stvo Kazanskogo universiteta (in Russian).

Sheref G. (1916). "Turkic-Tatar history" (Work by Zaki Walidi). Shura, 13, 311-314 (in Tatar).

Our history (1912a). Shura, 18. 558-559 (in Tatar).

Our history (1912b). Shura, 19, 590-591 (in Tatar).

On our history (1909). Shura, 13, 391-393 (in Tatar).

On our history (1913). Shura, 1, 10-12 (in Tatar).

Usmanova D. (2004). Creating the National History of the Tatars: Historiographic and Intellectual Debates at the Turn of the Century. New imperial bistory of the post-Soviet space: collection of articles (library of the journal "Ab Imperio"). Ed. I.V. Gerasimov, S.V. Glebov, 
A.P. Kaplunovsky, M.B. Mogilner, A.M. Semenov. Kazan': Centr issledovanij nacionalizma i imperii, 109-126 (in Russian).

Usmanova D. The Search for Identity in the Era of Nationalism: Discussions about the "Muslim" and "Turkic-Tatar" Nation among Russian Volga-Ural Tatars in the early 20th Century. Istoriya. 2018. V. 9. Issue 8 (72) [Electronic resource]. Access for registered users. URL: http:// history. jes.su/s207987840002441-4-1 (circulation date: 15.12.2018). DOI: 10.18254/S0002441-4-1 (in Russian).

Usmanova D. (2013). "National Tatar press is the same everywhere...": Qualitative and quantitative characteristics of Tatar press (1905-1916). Simbirskij nauchnyj vestnik, 3 (13), 147153 (in Russian).

Uzemezchel (1912). On the turks. Shura, 23. 2-3 t.b. (in Tatar). 